\title{
ПРИЧИНИ, НАСЛІДКИ ТА СПОСОБИ ПОДОЛАННЯ ДЕМОТИВАЦІЇ ПЕРСОНАЛУ В СУЧАСНИХ УМОВАХ
}

\section{CAUSES, CONSEQUENCES AND WAYS OF OVERCOMING PERSONNEL DEMOTIVATION IN MODERN CONDITIONS}

\author{
Смірнова Катерина Володимирівна \\ кандидат економічних наук, доцент, \\ Одеський державний екологічний університет \\ ORCID: https://orcid.org/0000-0002-4680-8369 \\ Чабанюк Анастасія Сергіївна \\ студентка, \\ Одеський державний екологічний університет \\ ORCID: https://orcid.org/0000-0001-6741-7917 \\ Smirnova Kateryna, Chabaniuk Anastasiia \\ Odessa State Environmental University
}

\begin{abstract}
Стаття присвячена питанням визначення причин та наслідків виникнення демотивації персоналу організацій в сучасних умовах, а також пошуку способів подолання негативного впливу факторів демотивації. Охарактеризовано особливості прояву етапів демотивації, визначено причини негативного впливу окремих фракторів на зниження мотивації персоналу та наслідки, які можуть виникнути, проаналізовано та узагальнено демотивуючі чинники. Виявлено зв'язок у поведінці демотивованих працівників та поведінці колективу. Сфрормульовано шляхи попередження та подолання впливу демотивуючих фракторів на результативність праці. Окреслено напрями дій з боку керівних осіб організацій щодо зниження впливу або повного усунення демотивуючих фракторів. Виявлено можливі профрілактичні заходи щодо недопущення прояву демотивації персоналу.

Ключові слова: персонал, мотивація, демотивація персоналу, причини демотивації працівників, демотиваційні чинники, управління персоналом, керівництво.
\end{abstract}

Статья посвящена вопросам определения причин и последствий возникновения демотивации персонала организаций в современных условиях, а также поиску способов преодоления негативного влияния фракторов демотивации. Охарактеризованы особенности проявления этапов демотивации, определены причины негативного влияния отдельных факторов на снижение мотивации персонала и последствия, которые могут возникнуть, проанализированы и обобщены демотивирующие факторы. Выявлена связь в поведении демотивированных работников и поведении коллектива. Сорормулированы пути предупреждения и преодоления влияния демотивирующих фракторов на результативность труда. Обозначены направления действий со стороны руководящих лиц организаций по снижению влияния или полному устранению демотивирующих фракторов. Выявлены возможные профилактические меры по недопущению проявления демотивации персонала.

Ключевые слова: персонал, мотивация, демотивация персонала, причины демотивации работников, демотивирующие фракторы, управление персоналом, руководство.

The article focuses on the essence, manifestations, causes and outcomes of staff demotivation, the search for effective ways to cope with this phenomenon. Demotivation is a consequence of changes in the organization and personal life, a source of employees' discomfort that is almost inevitable in the organization long run of the organization. Besides, demotivation can be an energy source for some personnel, provoking them to act appropriately. Such cases need to be directed constructively by the leader. Identifying the staff demotivating factors is a key task of company management, as the consequences of demotivation of staff for organizations and individual employees might be critical and crucial. Visible peculiarities of demotivation stages are characterized. The reasons and the outcomes of negative influence on demotivation of personnel are defined. Demotivating factors are analysed and generalized. The correlation between the behaviour of demotivated members and team productivity was revealed. Preventive measures and the ways to overcome the demotivating factors impact on productivity are formulated. The article offers the organization leaders the list of actions how to work with the demotivated personnel, reduce the impact or eliminate demotivating factors. The importance of constructive feedback given by the management to their 
subordinates is outlined. The depicted BOFF-model (Behaviour - Outcome - Feelings - Future) serves to help in identifying problems, maintaining labour standards and work efficiency. Possible preventive measures to avoid any demotivation manifestation due to dissatisfaction with the task, concerns, resistance to innovation by staff are discovered. The offered methods for finding and diagnosing the causes of staff demotivation are aimed at recognizing demotivation onsets and their characteristics. The study results can serve as a theoretical basis for further motivation systems development in organizations, the decision-making process and changes implementation applying the offered methods to overcome any negative impact of demotivating factors.

Keywords: personnel, motivation, personnel demotivation, reasons for employee demotivation, demotivating factors, personnel management, management.

Постановка проблеми. В сучасних умовах постійної та достатньо жорсткої конкуренції в бізнес-середовищі постає необхідність забезпечення максимально едективної діяльності організації. Сьогодніуспіх бізнесу, перш за все, багато в чому залежить від результативності роботи колективу в цілому та роботи кожного окремого співробітника, а отже шлях до якісного управління персоналом ґрунтується на розумінні мотивів та потреб працівників організації. Залежно від мотивів, якими керується особа у трудовій діяльності, фрормується ії ставлення до роботи, а на саму трудову поведінку, в свою чергу, впливають різноманітні чинники, які можуть діяти в різних напрямах (здійснювати позитивний або негативний вплив) та з різною силою. Проблема мотивації праці стає все гострішою, але більшість керівників підприємств не приділяє належної уваги даному питанню, користуючись, як правило, стандартними схемами матеріального стимулювання та штрафрних санкцій, не враховуючи індивідуальних особливостей працівників та специфріки діяльності організації. Тому в разі появи чинників негативного впливу на трудову поведінку персоналу організація стикається $з$ проблемою демотивації, яка проявляється у зниженні мотивації працівника і характеризується комплексом переживань людини, зумовленим цими негативними фракторами, зокрема: робота персоналу без належної енергії та ентузіазму, згасання концентрації на завданні, відстороненість, втрата ініціативи та відповідальності, небажання покращувати результати діяльності та байдужість, сприйняття працівниками перебування на робочому місці як просте проведення часу, апатія тощо.

Тому керівництву будь-якої сучасної компанії необхідно зосереджувати увагу не тільки на питаннях підвищення мотивації персоналу та збереження ії̈ на високому рівні, а й працювати з демотивацією підлеглих.

Аналіз останніх досліджень і публікацій. Вирішення проблеми впливу демотиваційних фракторів наразі є одним 3 першо- чергових завдань в економічний науці та об'єктом пильної уваги науковців і фрахівців, серед яких: Адельсеітова Е. та Асанова 3. [1], Іваницька С., Галайда Т. та Дяченко Ю. [2], Колот А., Кузнецова К. [3], Мирошниченко Ю. і Головатюк А. [4], Стегостенко І. [5], Стуканова Н., Татомир І. [6], Тетерук А. [7] та інші.

Виділення невирішених раніше частин загальної проблеми. Якщо питанням підвищення матеріальної та нематеріальної мотивації персоналу приділено багато уваги в науковому середовищі, то чинники, які викликають демотивацію персоналу досліджені недостатньо, що викликає необхідність подальших досліджень та систематизації інфрормації.

Формулювання цілей статті (постановка завдання). Метою статті $€$ аналіз причин виникнення демотивації персоналу організацій та виявлення внутрішньоорганізаційних чинників впливу на неї, а також пошук способів подолання цього явища.

Виклад основного матеріалу дослідження. Демотивацію можна вважати складним динамічним процесом формування взаємопов'язаних та взаємообумовлених соціальних і економічних демотивів трудової поведінки людини, які стають спонукальною причиною, поштовхом до неесективної трудової діяльності, спрямованої на невиконання поставлених завдань [6].

Демотивація - це не просто зниження мотивації, це цілий комплекс переживань людини, який своєрідно проявляється як у відносинах, так і в їі діяльності. 3 іншого боку, демотивація, як зворотний процес мотивації, - це зниження стимулів для досягнення цілей організації, викликане ослабленням або повною відсутністю впливу сил, які могли б змусити співробітників працювати на необхідному рівні зусиль, старанності, наполегливості та сумлінності. За дослідженням Інституту Геллапа, самостійно мотивовано лише 13\% працівників по всьому світу [8]. Тому мотивація співробітників та боротьба з демотиваторами - одне з ключових завдань керівника. 
Незацікавлені роботою співробітники невигідні для організації, оскільки вони надають негативний приклад іншим і з часом до думки негативно налаштованої людини прислухається дедалі більше колег, падає ефективність праці та прибутковість організації в цілому. Прояви демотивації персоналу в організації негативно впливають на настрої всередині колективу, тому відсутність оперативного втручання з боку керівництва в цей процес може спровокувати відтік персоналу та призвести до зростання плинності кадрів. В таких ситуаціях, як правило, першими покидають організацію найбільш кваліфіковані кадри, яким простіше та легше працевлаштуватись в інших структурах. Для керівництва таке явище створює додаткові ризики, пов'язані не тільки 3 погіршенням емоційного стану персоналу, який залишився в організації, а також зі змінами у репутації самої організації, яка потрапляє в категорію таких, що не цінують перспективних працівників [3].

Процес демотивації носить накопичувальний характер і відбувається поступово в кілька етапів (табл. 1), але не можна сказати, що кожна особа проходить через усі етапи
[4]. Звичайно, у кожного працівника реакція носить індивідуальний характер, але $є$ загальні риси для всіх.

Настання 3 етапу демотивації персоналу провокує різні сценарії подальшого розвитку ситуації. Досвідчені топ-менеджери, впевнені у собі, своїх знаннях та навичках і висококвалісрікований персонал, затребуваний на ринку, як правило, обирають сценарій звільнення і працевлаштування в іншу компанію або навіть перехід у фрріланс. Інша категорія працівників, яким не вдається знайти бажане нове місце роботи або які пов'язані з роботодавцем довгостроковими зобов'язаннями, стають заручниками ситуації, залишаються працювати в організації, але при цьому людина сприймає роботу і компанію як «покарання», як неминучу каторгу, а в її поведінці домінують апатія, пригніченість, страх перед роботою тощо.

До втрати мотивації часто призводить і емоційне вигорання працівників. Синдром вигорання на професійний мові також називають демотивацією. Етапи демотивації та стадії вигорання мають схожі прояви.

Результатом демотивації працівників може бути зниження задоволеності робо-

Етапи демотивації персоналу

Таблиця 1

\begin{tabular}{|c|c|}
\hline Етап демотивації & Характеристика \\
\hline $\begin{array}{c}1 \text { етап - «легкий } \\
\text { стрес» або скрита } \\
\text { стадія }\end{array}$ & $\begin{array}{l}\text { У співробітника легкий стрес або дискомфорт. Він намагається } \\
\text { зрозуміти, з чим пов'язаний його дискомфорт - з керівництвом, } \\
\text { колективом або організацією в цілому. Зовні це проявляється слабо, } \\
\text { може бути непомітним, працівник, як і раніше, працює в робочих } \\
\text { процесах, легко та позитивно контактує з колегами та керівництвом, } \\
\text { але, водночас, переживає легкий стрес «в собі», його долають } \\
\text { зсередини сумніви (чи цінують його в компанії, чи можливе кар'єрне } \\
\text { зростання на займаній посаді, чи подобається взагалі сама діяльність } \\
\text { тощо). Тому будь-які зміни чи відхилення від звичайної поведінки } \\
\text { співробітника повинні насторожити безпосереднього керівника. В } \\
\text { таких ситуаціях велике значення має управлінська та соціальна } \\
\text { компетентність безпосереднього керівника, його вміння помітити те, що } \\
\text { ще яскраво не виражено. }\end{array}$ \\
\hline $\begin{array}{c}2 \text { етап - «відкрите } \\
\text { невдоволення» }\end{array}$ & $\begin{array}{l}\text { Співробітник може ігнорувати доручення, рекомендації і зворотний } \\
\text { зв'язок з керівництвом, ухилятися від виконання завдань з незначних } \\
\text { приводів, демонструвати агресивність, роздратування, вступати в спори } \\
\text { з керівником та клієнтами, задавати провокаційні питання колегам тощо. } \\
\text { На цьому етапі будь-які суперечливі вказівки керівника породжують у } \\
\text { демотивованого працівника почуття власного безсилля, він починає } \\
\text { застосовувати демонстративну поведінку, щоб зарекомендувати себе з } \\
\text { кращого боку, і водночас, зробити керівника винним у невдачі, але при } \\
\text { цьому підсвідомо такий працівник все ще сподівається на зміну ситуації. } \\
\text { В цей період працівник намагається уникати контактів з безпосереднім } \\
\text { керівником, більш активно цікавиться пошуками іншої роботи. }\end{array}$ \\
\hline $\begin{array}{l}3 \text { етап - повне } \\
\text { «відчуження» } \\
\text { співробітника від } \\
\text { керівництва та від } \\
\text { компанії в цілому }\end{array}$ & $\begin{array}{l}\text { Співробітник втрачає бажання до співпраці та інтерес виконувати } \\
\text { роботу, частіше конфоліктує з колегами через розчарування у керівництві, } \\
\text { у компанії та у своїй роботі. Людина обмежує до мінімуму свої посадові } \\
\text { обов'язки, не проявляє ініціативу, часто саботує роботу і повністю } \\
\text { ігнорує рекомендації керівника, намагається відмежуватися від компанії. }\end{array}$ \\
\hline
\end{tabular}


тою, яка має емоційні та поведінкові ознаки: підвищення схильності до конфрліктів, дратівливість, втома, непунктуальність, частіші прогули через хворобу, порушення працездатності та технологічної дисципліни, прихований саботаж, суперечки з керівництвом, зниження інтересу до роботи, зниження готовності до співпраці з колегами та керівництвом, зниження прихильності організації та тенденція до зміни робочих місць.

Демотивація персоналу відбивається не тільки на зниженні показників ефективності праці, негативно впливає на внутрішній психологічний клімат та корпоративну культуру, призводить до зростання плинності кадрів, а також може призвести до погіршення іміджу та репутації організації, падіння показників залученості та лояльності, скорочення кількості партнерів та інвесторів, зростання кількості незадоволених споживачів та зниження якості обслуговування, зменшення обсягів реалізації товарів і послуг, втрати конкурентоспроможності на ринку тощо. Тому якщо керівництво в оперативному порядку не почне виявляти так званих «мотиваційних кілерів», тобто шкідливі чинники, які вбивають мотивацію персоналу краще, ніж криза або відсутність премій тощо, та не почне розробляти план дій зі зниження демотивації - це може призвести до критичних наслідків.

Слід зазначити, що «вірус» демотивації може поступово охопити більшу частину або навіть увесь колектив, тому своєчасна реакція на розвиток демотивації персоналу дозволить уникнути складнощів та зростання плинності кадрів, особливо високопрофресійних [4].

Розглянемо найбільш розповсюджені причини демотивації працівників.

1. Постійні стресові навантаження. Дана причина часто зустрічається у багатьох співробітників компанії, але далеко не у всіх вона призводить до демотивації: багато що залежить від ступеня складності завдань, підтримки співробітника з боку керівника і колективу, індивідуальних особливостей людини, стану розвитку організації тощо [7].

Цей чинник особливо підсилився в умовах пандемії COVID-19, коли багато компаній збанкрутіли, а більшість - суттєво скорочують власні штати та бюджети. За таких умов працівники відчувають небезпеку та страх, починають сумніватися у своїй компанії, перебувають у стані стресу. Люди втрачають запал і знижується продуктивність. По-перше, це природна реакція організму на стан страху, стресу та тиску. Співробітник, особливо інте- лектуальної праці, не може ефективно працювати в такому стані, швидко втомлюється, має менше енергії, не може зібрати думки та сконцентруватися. По-друге, працівник не вбачає необхідності напружуватись, оскільки вважає, що організація може найближчим часом піти на дно, звільнити його, не виплатити заробітну плату тощо. Якщо співробітник і до цього був не дуже залучений і раніше намагався уникнути роботи, то в таких умовах у нього для цього є чудовий привід і аргумент.

Рішення даної проблеми полягає в тому, що керівнику $\epsilon$ сенс переглянути цілі співробітника, його завантаженість і при необхідності перерозподілити завдання у підрозділі. Якщо стресові навантаження пов'язані 3 недостатнім рівнем розвитку навичок або відсутністю належного досвіду, то співробітника варто відправити на навчання. В разі кризового періоду в організації керівник регулярно повинен спілкуватися зі співробітниками про поточний стан компанії, її успіхи, проблеми, перспективи та стратегії (зміни у стратегії) і як наслідок - працівник буде більш впевнений, що профресіоналізм топ-менеджерів дає якісне розуміння, куди вести компанію, що їм можна довіряти і що з ними буде безпечно.

2. Наявність більш високої кваліфрікації для виконання роботи. Деякі співробітники не прагнуть до кар'єрного або професійного росту, у них немає амбіцій стати керівником, вони задоволені своїм поточним становищем, зарплатою і рівнем професіоналізму. Однак деякі з таких співробітників змушені виконувати роботу, яка набагато вище їх навичок та квалісрікації.

Для керівника це сигнал, що співробітник має потребу в навчанні або підвищенні кваліфрікації та йому потрібно надати таку можливість, щоб він зміг виконувати задану роботу. Якщо немає можливості направити людину на навчання, то $€$ альтернатива - переведення працівника в інший відділ або на іншу посаду, де він відчуватиме професійну впевненість і покаже більш ефрективний результат [7].

3. Недооцінювання навичок співробітника, тобто рівень роботи нижче, ніж кваліфрікація працівника. Амбітні співробітники, метою яких $\epsilon$ професійне та кар'єрне зростання, якими рухає самореалізація, іноді змушені виконувати роботу, яка не дозволяє реалізувати свої навички і $€$ нижчою їх рівня квалісрікації. Потрапляючи в подібну ситуацію, співробітники відчувають розчарування, яке згодом переростає в демотивацію. 
Такому працівнику треба надати додаткові можливості проявити себе. Наприклад, включати в проєкти, де є можливість продемонструвати свій рівень кваліфікації та компетенцій. Однак цей варіант працює в короткостроковій перспективі. Тому за можливістю варто такого співробітника перевести на більш високу посаду, в іншому випадку тривалість його перебування в організації буде недовгою [7].

Також фрахівці 3 управління персоналом рекомендують на етапі підбору персоналу не приймати на роботу осіб з більш високою компетентністю, ніж потрібно для виконання конкретних посадових обов'язків, за винятком ситуації, якщо такому працівнику буде запропоноване просесійне зростання в найближчій перспективі [7].

4. Рутинність та одноманітність роботи. Для окремих працівників в трудовій діяльності важливі інтерес, новизна, різноманітність завдань, а також можливість швидко бачити власний результат. Знизити або взагалі відбити бажання працювати в таких осіб може відсутність цікавих проектів, нудна та рутинна робота, тупикові перспективи, байдужа позиція керівництва до заслуг окремих співробітників, оскільки все це не дозволяє працівнику проявити себе і побачити можливості для профресійного розвитку.

Така ситуація вимагає від керівника дій щодо надання розмаїтості в роботі працівника: включати його в нові проекти, переводити в інші підрозділи, відправляти на навчання для доручення виконання нових завдань або розробку нового продукту чи послуги, розширювати пакет функціональних обов'язків тощо. Також можна залучати працівника до наставництва та консультування під час навчання новоприбулих співробітників компанії, тим самим створюючи умови для отримання ним нового досвіду і можливості демонстрації своєї експертності та фраховості.

5. Мінливість і нестабільність в роботі. Деякі працівники виділяють важливість для них стабільності та передбачуваності в роботі, оскільки самі важко адаптуються до змін і досить часто реагують опором на будьякі інновації з боку керівництва. В таких осіб часті, слабо або непрогнозовані зміни можуть викликати демотивацію.

В таких ситуаціях керівнику варто впроваджувати зміни поступово, роз'яснюючи працівникам цілі змін, їх переваги та очікувані результати. А самих співробітників бажано залучати до розроблення та впровадження змін, а також давати час для їх адаптації до нового.
6. Високий рівень самостійності в роботі та відповідальності в прийнятті рішень. Робота деяких співробітників передбачає більшу самостійність у вирішенні завдань, організації і веденні робочих проектів з нуля. При цьому їм самим потрібні зовнішня підтримка, постійний контроль, а самостійність і відповідальність викликають дискомфрорт і стрес.

Керівнику важливо правильно розподіляти завдання між працівниками, враховуючи їх рівень компетенції, самостійності в прийнятті рішень і готовність нести відповідальність за результати, психологічні особливості людини. Однак, окрім демотивації працівника, цей чинник може мати і інший прояв - слід передбачати ситуації недосягнення або часткового досягнення поставленої мети, відхід від відповідальності, тож керівнику варто попередньо з'ясувати, чи хоче, може і готовий працівник до самостійності і відповідальності за делеговані йому завдання [7].

7. Низький рівень делегування або довіри. Демотивація може проявлятись у амбітних співробітників, для яких важливі самостійність в ухваленні рішень, готовність нести відповідальність за результати, а також орієнтованих на кар'єрне зростання. Усередині чітко побудованої організаційної структури зі зрозумілими правилами люди ще більше починають цінувати автономію. У таких умовах відсутність постійного контролю - це свідчення довіри до співробітника та впевненості в ньому, тоді як тотальний контроль показує недовіру, принижує фрахівця, знищує ініціативу та знижує активність. Кожен працівник хоче відчувати владу над власним часом та енергією, тому при налагоджених процесах поступове пом'якшення нагляду та заохочення самоконтролю - вірний спосіб надати кращим співробітникам підвищений рівень комсрорту.

В даному випадку керівнику важливо розпізнати потенціал, амбіції співробітника і надати йому більшу самостійність, встановивши загальні правила роботи. Якщо у співробітника $є$ відповідні компетенції і готовність, то керівник може почати делегувати деякі свої завдання, що може бути сприйнято співробітником як показник високої довіри і визнання професіоналізму. Також важливим $€$ налаштування постійного каналу зворотного зв'язку для отримання сповіщення або запитів у разі складних та нестандартних ситуацій та майданчика для регулярних дискусій.

8. Відсутність кар'єрного зростання. Коли талановитий, амбіціозний фрахівець не 
бачить перспектив розвитку, він може втратити інтерес до роботи, а його відповідальність по відношенню до обов'язків - знизитись. Цей чинник викликає демотивацію у так званих кар'єристів - співробітників, які прагнуть до кар'єрного зростання або у осіб, які занадто довго (понад 3-5 років) працювали на одній посаді. В такому випадку важливий принцип відкритості: керівник повинен прямо повідомити працівнику про відсутність можливості кар'єрного росту в компанії. Якщо ж підвищення в перспективі $€$ можливим, то керівник відкрито має проіноормувати через який час і чи може саме цей співробітник претендувати на більш високу посаду.

У $100 \%$ найрозумніших співробітників $€$ власні чіткі кар'єрні цілі і саморозвиток для них не пусте слово, тож завдання керівника постійно спілкуватись за такими працівниками, дізнаватись про їхні прагнення та очікування, показувати варіанти, де їхні особисті інтереси та потреби компанії збігаються. Якщо працівника необхідно утримати в компанії, то компенсувати відсутність кар'єрного росту можна підвищенням заробітної плати, професійним навчанням, розширенням повноважень, новими завданнями, короткостроковими цікавими проектами, схваленням експериментів і розумного ризику тощо. Відмінним рішенням може стати горизонтальний розвиток - саме так можливо утримувати фрахівця, якщо за певних причин керівник немає можливості підвищити його в посаді. Якщо все це призведе до підвищення ефективності та розвитку навичок обдарованого співробітника, це величезний бонус для всієї компанії.

9. Іанорування раціоналізаторських пропозицій і ініціативи. Існує категорія співробітників, у яких завжди достатньо ідей для вирішення певних проблем та подолання нестандартних ситуацій. Якщо працівник побачив можливість щось оптимізувати, удосконалити, зробити краще, йому набагато складніше продовжувати діяти по-старому. Але, якщо керівник підтримує консервативні погляди і навмисно ігнорує ідеї або не має достатнього часу для аналізу ідеї, ініціативи залишаються без уваги. В результаті у працівника знижується мотивація і він переходить в стан інертності і у режим роботи «з дев'яти до шести», з'являється формальне ставлення до роботи. Якщо ж керівник бажає, щоб працівники були лояльні і сприймали компанію як власну дитину, їм слід надавати можливість вкласти в її розвиток свої ідеї та енергію. В такому разі досить важливо розробити в організації систему фріксації, тестування та реалізації ініціатив, наприклад, запустити конкурс інновацій 3 підведенням підсумків (протягом місяця, кварталу, півріччя) та реалізацією кращих пропозицій і винагородою їх авторів. Також досить важливо спілкуватись 3 такими працівниками особисто, прислухатись до них, заохочувати гарні ідеї підтримкою.

10. Нестача визнання та похвали з боку керівника або колективу. Останнім часом моральна мотивація стає все більш дієвою, а похвала керівника - це один із найважливіших фракторів нематеріальної мотивації співробітників, тому для частини працівників вагоме значення має відкрите визнання значущості їх просресіоналізму і результатів роботи. Такі співробітники зазвичай орієнтовані на зовнішню оцінку, для них важлива думка оточення, усвідомлення своєї цінності та важливості.

Найпростіший спосіб подолання цієї причини - проводити регулярні планерки, особисті зустрічі зі співробітниками та відділами, приділяти більше уваги працівникам, частіше публічно схвалюючи за високі результати роботи тих, хто цього заслуговує, висувати на внутрішньоорганізаційні нагороди та не недооцінювати важливості слів [7].

11. Неконструктивна критика. Одним із найголовніших руйнівників мотивації $€$ неконструктивна (деструктивна) критика співробітників. За фрормою така критика означає висловлення в некоректному емоційному тоні, публічно, з підвищенням голосу, в образливій манері, із зайвим сарказмом, з переходом на особистості, можливо із застосуванням некоректних виразів чи навішуванням ярликів, а за змістом вона стає деструктивною, якщо висловлена у загальній формі, на яку важко щось заперечити, без конкретики, без спроби знайти позитивні елементи всієї роботи чи самого працівника, без переходу на конструктивне обговорення початкових очікувань. Деструктивна критика призводить до появи негативних емоцій та серйозних психологічних наслідків для працівника i, як наслідок, неможливість адекватно сприймати інорормацію й виконувати роботу; знижує самооцінку, впевненість у собі та своїх здібностях, як наслідок, знижується працездатність людини; призводить до напруженої атмоссрери в колективі і викликає бажання зміни місця роботи - все це явно виражені ознаки демотивації працівника.

Важливо розуміти, що використання тільки заохочень не сприяє розвитку фрахівців і осо- 
бистісному зростанню управлінців. Керівнику слід використовувати критику для допомоги, оскільки правильно виражена критика допомагає звернути увагу на слабкі місця у роботі, критикувати слід не саму людину, а конкретні дії, спираючись виключно на фракти і достовірну інорормацію. Конструктивна критика $€$ інструментом, за допомогою якого наставник може спонукати підопічного до навчання через негативні емоції, які $€$ сильнішим стимулятором активності. Однак для цього важливо відтворити ефективний зворотний зв'язок всередині організації, який допомагає підвищувати професіоналізм, підтримувати робочі стандарти, актуалізувати інорормацію, виявляти проблеми, удосконалювати команду. Важливо навчити персонал давати конструктивний зворотний зв'язок. Для цього фрахівці рекомендують освоювати в організаціях модель ПРПМ (BOFF): Поведінка/Дії (Behaviour) - Результат/ есрект дій (Outcome) - Почуття (Feelings) Майбутнє (Future) (табл. 2) [5].

Уміння давати та сприймати грамотний зворотний зв'язок - це запорука комсрортної та успішної роботи колективу, можливість уникнути конфрліктів та налагодити діалог керівника з колективом.

12. Особистість керівника і (або) його стиль управління. Деякі співробітники орієнтовані на особистість керівника, а їх ефрективність і результативність залежать від обраного ним стилю управління. Такий тип персоналу дуже чутливий до реакцій керівника. Демотивацію викликають ситуації, коли стиль управління не підходить для співробітника. Якщо керівник не ставить чітких термінів, не прислухається до співробітників, намагається все зробити сам і часто дає вихід емоціям, це знищить будь-яку мотивацію. Велику роль грає і сама особистість керівника. Коли авторитет начальства незаперечний (зовнішній вигляд, справедливість, увага до особистого та сімейного життя підлеглих, абсолютна твердість слова, профресіоналізм або досконале знання своєї справи), найменше його слово навіть погляд діють миттєво і в потрібному напрямку. Дослідження Gallup показало, що мотивація і рівень залученості співробітників на 70\% залежить від особистості та дій керівника, і важливо налагодити комфортну взаємодію начальства 3 підлеглими, щоб підвищити ефрективність їхньої роботи [8]. Звільнення працівників відбувається не через роботу, а через начальство.

Керівнику необхідно попрацювати над лідерськими навичками, більше уваги звертати на свій стиль управління (проводити саморефрлексію), вміти адаптувати стиль управління до реалій і поточної ситуації, а також враховувати індивідуальні якості підлеглих, спробувати більше прислухатися до підлеглих та навчитися делегувати обов'язки [7].

13. Наявність в колективі колег-демотиваторів. Не лише керівник винен у відсутності мотивації у своїх підлеглих. Якщо в колективі $€$ співробітники, які зводять нанівець усі ініціативи саркастичними зауваженнями, незадоволені з будь-якого приводу або скандалять через дрібниці, вони заражають негативом колектив. Якщо є так звані «ледарі», які сидять у соціальних мережах, висять на телефоні, вирішують на роботі особисті проблеми, вони провокуються запозичення такої моделі поведінки колегами, збиваючи робочий настрій, отже, продуктивність знижується. Також дратувати можуть неврівноважені особи з підвищеною емоційною реакцією, любителі пожалітися керівництву на колег, улюбленці.

Таблиця 2

Модель BOFF

\begin{tabular}{|c|l|}
\hline Компонента & \multicolumn{1}{|c|}{ Характеристика } \\
\hline $\begin{array}{c}\text { Поведінка/Дії } \\
\text { (Behaviour) }\end{array}$ & $\begin{array}{l}\text { Виклад власних спостережень за поведінкою колеги, не узагальнюючи } \\
\text { і без емоційного забарвлення: потрібні фракти, цифри та деталі - це } \\
\text { дозволить людині зрозуміти, де вона помиляється і що це помітно для } \\
\text { всіх, тобто критика є об'єктивною. }\end{array}$ \\
\hline $\begin{array}{c}\text { Результат/едект дій } \\
\text { (Outcome) }\end{array}$ & $\begin{array}{l}\text { Озвучування наслідків, які відбулися та/або можливо відбудуться } \\
\text { внаслідок зазначеної події/поведінки особи для бізнесу, а також для } \\
\text { результатів та перспектив самого працівника. }\end{array}$ \\
\hline $\begin{array}{c}\text { Почуття } \\
\text { (Feelings) }\end{array}$ & $\begin{array}{l}\text { Висловлювання своїх почуттів, емоцій, ставлення до того, що } \\
\text { відбувається. }\end{array}$ \\
\hline $\begin{array}{l}\text { Майбутнє } \\
\text { (Future) }\end{array}$ & $\begin{array}{l}\text { Обговорення майбутнього через запитання працівнику, що він готовий } \\
\text { зробити/вжити для того, щоб у майбутньому певна подія/поведінка } \\
\text { не мала місця. Важливо, щоб зворотний зв'язок став відправною } \\
\text { точкою для позитивних змін і результатів до певної дати (терміни якої } \\
\text { завчасно обговорено). }\end{array}$ \\
\hline
\end{tabular}


Фахівці виокремлюють кілька типів співробітників компаній, які можуть негативно діяти на колег та виступати демотиваторами. Серед таких типів: «вампіри» - особи, які висмоктують енергію з оточуючих і виконують свої обов'язки виключно в рамках встановленого робочого часу та обов'язків; «зомбі» неефективні працівники 3 відсутньою мотивацією, безініціативні, ніколи не беруть на себе відповідальність і можуть заражати колег; «неряхи» - працівники, які не стежать за собою, що робить нестерпним перебування 3 ними в одному приміщенні; «песимісти» - завжди всім незадоволені працівники, не здатні стримувати негатив, який вони виплескують на колег з будь-якого приводу; «розкрадачі часу» - співробітники, які готові багато, довго і красиво говорити ні про що, але такі люди вибивають із робочого ритму, витрачають свій та чужий час.

Очевидно, що керівник повинен негайно реагувати на будь-які зміни, що відбуваються в команді та приділяти особливу увагу атмосфрері, що панує в організації, оскільки співробітники повинні бути в змозі розслабитися в колі колег і насолоджуватись робочим процесом. Тому керівникові слід взяти таких працівників-демотиваторів під особистий контроль: проводити 3 ними бесіди для виявлення причин незадоволеності та (або) невідповідної поведінки, переводити за можливістю в інший структурний підрозділ або спрямовувати їх роботу на індивідуальні завдання тощо.

14. Деструктивні відносини у колективі і відсутність згуртованості. Для деяких співробітників важливі колектив і відносини всередині нього. Такі люди вже на етапі співбесіди промовляють про важливість впливу команди на ефрективність роботи, власну працездатність і настрій. Якщо співробітник $€$ командним гравець, для якого важлива підтримка контакту протягом роботи, відчуття дружнього плеча, а в колективі превалюють одинаки, орієнтовані тільки на роботу і своє особисте благополуччя, настає демотивація. На фрормування корпоративної культури впливає і керівник, він $€$ транслятором цінностей компанії. Ще на етапі підбору персоналу важливо визначити, до якого типу належить здобувач - до командного гравця або до одинака, і співвіднести його сумісність 3 колективом.

Якщо помічається подібна демотивація у співробітника, важливо оцінити, чому співробітник демотивований і що не так з командою. Рішенням можуть бути тренінги з командоутворення, спільні тімбілдинги, робота над завдан- ням усього колективу. Іноді деякі співробітники працюють дистанційно і колективу практично немає. У таких випадках краще приймати на роботу одинаків, адже командний гравець буде постійно демотивований, а з боку керівника буде потрібно досить багато уваги.

Зниження мотивації може відбуватися протягом досить тривалого часу або статися в один момент, залежно від значущості негативних фракторів для конкретного працівника та тривалості їхнього впливу. Тому керівництву досить важливо вчасно виявляти фрактори, що сприяють демотивації персоналу. Для цього в розпорядженні керівників є низка методів пошуку та діагностики причин демотивації персоналу таких як [1]: спостереження та особисті бесіди, інтерв'ю, анонімні опитування із залученням власної служби з управління персоналом або зовнішніх незалежних консультантів, за допомогою яких уважний керівник може розпізнати характерні риси та початкові прояви демотивації працівника i вчасно відреагувати.

Висновки. Демотивація сприяє руйнуванню відносин в колективі, гармонійної цілісності трудової діяльності та життя людини, що провокує появу трудової апатії, втрату профресіоналізму як результат небажання і незацікавленість у подальшому розвитку працівника, погіршення трудової активності, зниження ефективності праці тощо. Виходячи 3 цього, забезпечення ефективності праці вимагає підвищення мотивації трудової діяльності працівників, що неможливо без усунення демотиваторів. Вчасно виявлені причини демотивації персоналу можуть підвищити вірогідність повернення працівнику інтересу до праці, але це залежатиме від етапу розвитку демотивації в конкретної особи.

Співробітники не схожі один на одного, вони знаходяться на різних етапах свого життя та мотивація у кожного індивідуальна: для одного важливе навчання, для іншого незалежність та довіра. Вибудовування відносин в колективі, взаємодія керівників та підлеглих повинні спрямовуватись на уникнення будь-яких проявів демотивації. Оскільки персонал $€$ ключовим ресурсом та запорукою успіху організації, основним завданням керівництва $€$ створення відповідних сприятливих умов для ефективної, комфрортної праці.

Досить часто керівники більше уваги, зусиль та ресурсів прикладають для мотивації персоналу, але не помічають чинників, які дають зворотний ефект, негативно впливаючи на трудову діяльність працівників. Подібні 
упущення можуть обернутися на початковому етапі прихованою демотивацією персоналу, яка без оперативних дій здатна нанести суттєві збитки організації. Наразі проблема демотивації працівників набуває все більших масштабів та все більше чинників провокують незадоволеність персоналу, тому постійний аналіз та діагностика таких фракторів, фрормування ефективного зворотнього зв'язку в організації можуть допомогти утримати цінних для організації фрахівців та стабілізувати колектив і його результати.

\section{СПИСОК ВИКОРИСТАНИХ ДЖЕРЕЛ:}

1. Адельсеитова Э.Б., Асанова 3.С. Особенности демотивации труда работников. Культура народов Причерноморья. 2013. № 254. C. 41-43. URL: http://dspace.nbuv.gov.ua/bitstream/handle/123456789/92126/08Adelseitova.pdf?sequence $=1$

2. Іваницька С.Б., Галайда Т.О., Дяченко Ю.О. Проблеми виявлення та подолання негативного впливу чинників демотивації персоналу на результативність праці. Економіка і суспільство. 2018. Випуск 19. С. 409-416. URL: https://economyandsociety.in.ua/journals/19_ukr/62.pdf

3. Кузнецова Е.А. Демотивация персонала: причины, фракторы, методы устранения. Современные исследования социальных проблем. 2012. № 11(19). URL: https://cyberleninka.ru/article/n/demotivatsiya-personalaprichiny-faktory-metody-ustraneniya

4. Мирошниченко Ю.В., Головатюк А.І. Проблеми демотивації персоналу та шляхи ії подолання. Молодий вчений. 2015. № 12(27). Частина 2. С. 81-84. URL: http://molodyvcheny.in.ua/files/journal/2015/12/58.pdf

5. Стегостенко И. Методы управления: обратная связь в работе руководителя. URL: https://www.liga.net/ all/opinion/metody-upravleniya-obratnaya-svyaz-v-rabote-rukovoditelya

6. Татомир І.Л. Вплив демотиваційних фракторів на формування поведінки працівника в умовах інфрормаційного суспільства. Економіка та держава. 2008. № 11. С. 37-39. URL: http://nbuv.gov.ua/UJRN/ecde_2008_11_12

7. Тетерук А. 11 причин демотивации сотрудников. Как это разрешать. URL: https://officelife.media/ article/people/23538-10-prichin-demotitivatsii-sotrudnikov-kak-eto-razreshat/

8. What Is Employee Engagement and How Do You Improve It? Gallup. URL: https://www.gallup.com/ workplace/285674/improve-employee-engagement-workplace.aspx

\section{REFERENCES:}

1. Adelseitova E.B., Asanova Z.S. (2013) Osobennosti demotivatsii truda rabotnikov. Kultura narodov Prichernomorya, no. 254, pp. 41-43. Retrieved from: http://dspace.nbuv.gov.ua/bitstream/handle/123456789/ 92126/08-Adelseitova.pdf?sequence=1 (in Russian)

2. Ivanytska S.B., Halaida T.O., Diachenko Yu.O. (2018) Problemy vyiavlennia ta podolannia nehatyvnoho vplyvu chynnykiv demotyvatsii personalu na rezultatyvnist pratsi. Ekonomika i suspilstvo, vol. 19, pp. 409-416. Retrieved from: https://economyandsociety.in.ua/journals/19_ukr/62.pdf (in Ukrainian)

3. Kuznetsova E.A. (2012) Demotivatsiya personala: prichiny, faktory, metody ustraneniya. Sovremennyie issledovaniya sotsialnyih problem, no. 11(19). Retrieved from: https://cyberleninka.ru/article/n/demotivatsiya-personalaprichiny-faktory-metody-ustraneniya (in Russian)

4. Myroshnychenko Yu.V., Holovatiuk A.I. (2015) Problemy demotyvatsii personalu ta shliakhy yii podolannia. Molodyi vchenyi, no. 12(27), ch. 2, pp. 81-84. Retrieved from: http://molodyvcheny.in.ua/files/journal/2015/12/58.pdf (in Ukrainian)

5. Stegostenko I. Metody upravleniya: obratnaya svyaz v rabote rukovoditelya. Retrieved from: https://www.liga.net/ all/opinion/metody-upravleniya-obratnaya-svyaz-v-rabote-rukovoditelya (in Russian)

6. Tatomyr I.L. (2008) Vplyv demotyvatsiinykh faktoriv na formuvannia povedinky pratsivnyka $v$ umovakh informatsiinoho suspilstva. Ekonomika ta derzhava, no. 11, pp. 37-39. Retrieved from: http://nbuv.gov.ua/UJRN/ ecde_2008_11_12 (in Ukrainian)

7. Teteruk A. 11 prichin demotivatsii sotrudnikov. Kak eto razreshat. Retrieved from: https://officelife.media/ article/people/23538-10-prichin-demotitivatsii-sotrudnikov-kak-eto-razreshat/ (in Russian)

8. What Is Employee Engagement and How Do You Improve It? Gallup. Retrieved from: https://www.gallup.com/ workplace/285674/improve-employee-engagement-workplace.aspx 